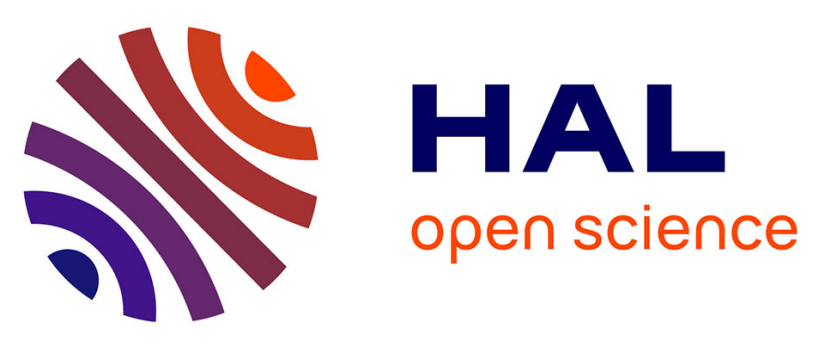

\title{
Spatial and temporal variations of particulate organic matter from Moselle River and tributaries: A multimolecular investigation
}

Mathieu Le Meur, Laurence Mansuy-Huault, Catherine Lorgeoux, Allan Bauer, Renaud Gley, Delphine Vantelon, Emmanuelle Montarges-Pelletier

\section{To cite this version:}

Mathieu Le Meur, Laurence Mansuy-Huault, Catherine Lorgeoux, Allan Bauer, Renaud Gley, et al.. Spatial and temporal variations of particulate organic matter from Moselle River and tributaries: A multimolecular investigation. Organic Geochemistry, 2017, 110, pp.45-56. 10.1016/j.orggeochem.2017.04.003 . hal-01939684

\section{HAL Id: hal-01939684 https://hal.science/hal-01939684}

Submitted on 29 Nov 2018

HAL is a multi-disciplinary open access archive for the deposit and dissemination of scientific research documents, whether they are published or not. The documents may come from teaching and research institutions in France or abroad, or from public or private research centers.
L'archive ouverte pluridisciplinaire HAL, est destinée au dépôt et à la diffusion de documents scientifiques de niveau recherche, publiés ou non, émanant des établissements d'enseignement et de recherche français ou étrangers, des laboratoires publics ou privés. 
1 Spatial and temporal variations of Particulate Organic Matter from Moselle

2 River and tributaries: A multimolecular investigation

Mathieu Le Meur ${ }^{1,2}$, Laurence Mansuy-Huault ${ }^{1}$, Catherine Lorgeoux ${ }^{3}$, Allan Bauer ${ }^{1}$, Renaud Gley $^{1}$, Delphine Vantelon ${ }^{4}$, Emmanuelle Montargès-Pelletier ${ }^{1,5}$

${ }^{1}$ Laboratoire Interdisciplinaire des Environnements Continentaux, UMR 7360 CNRS-Université de Lorraine, 15 avenue du Charmois 54500 Vandouvre-lès-Nancy, France, mathieu.le-meur@univlorraine.fr

${ }^{2}$ Department of geological sciences, 241 Wiliamson Hall, 1843 Stadium Road, Gainesville, FL 32611, USA, mlemeur@ufl.edu

${ }^{3}$ GeoRessources, UMR 7359 CNRS-Université de Lorraine, Campus des Aiguillettes, BP 70239, F54506 Vandouvre-lès-Nancy, France

${ }^{4}$ Synchrotron SOLEIL Synchrotron SOLEIL L'orme des merisiers Saint Aubin BP48 91192 Gif sur Yvette cedex

${ }^{5}$ LTER Zone Atelier Moselle - Laboratoire Interdisciplinaire des Environnements Continentaux, UMR 7360 CNRS-Université de Lorraine, 15 avenue du Charmois 54500 Vandouvre-lès-Nancy, France

\section{ABSTRACT}

The spatial and temporal composition of organic matter (OM) was investigated in the Moselle watershed (Lorraine, France). The spatial composition was studied using different stations along the river and four tributaries. In addition, one anchor station was used in order to better understand the temporal OM composition during different hydrologic regimes and seasons. The first part of the organic characterization consisted of the extraction of the lipidic OM with an automatic extractor. The extracts were analyzed for their lipidic fatty acids (Lip-FAs), polycyclic aromatic hydrocarbons (PAHs) and sterols using gas chromatography-mass spectrometry (GC-MS). The insoluble fraction was also analyzed with thermochemolysis-GCMS (TMH-GC-MS) using tetramethylammonium hydroxide (TMAH) and lignin phenols, permethylated deoxy aldonic acids and refractory fatty acids (Ref-FAs) were analyzed. The results showed that one station, (Florange station) on the small Fensch stream tributary displayed variations in the composition of the molecular OM with higher microbial markers $\left(\mathrm{C}_{16: 1}, \mathrm{C}_{18: 1 \mathrm{w} 7}, \mathrm{C}_{18: 1 \mathrm{w} 9}\right.$, coprostanol $)$ inputted to the highly industrialized and urbanized areas in this small sub-catchment. The other stations showed rather similar organic composition (Lip- 
FAs, Ref-FAs, sterols, lignin compounds, PAHs) due to the size of the catchment $(10,000$ $\mathrm{Km}^{2}$ ) or the integrative state of the suspended particulate matter (SPM). The regime flow involved a decrease in SPM OM content as well as a decrease of the palmitoleic acid/palmitic acid $\left(\mathrm{C}_{16: 1} / \mathrm{C}_{16: 0}\right)$ ratio and

an increase

(stigmastanol+sitostanol+stigmasterol+sitosterol)/(cholesterol+cholestenol) $\quad\left(\mathrm{C}_{29} / \mathrm{C}_{27}(\mathrm{ST})\right)$ ratio revealing the presence of more allochthonous OM. The increase in regime flow was also correlated with a growing contribution of more degraded OM in the SPM that could be related to the leaching of subsurface soils from the watershed or to the remobilization of surface sediments. Seasonal variations were also observed, with a stronger contribution of autochthonous production during low flow level in summer. This work shows the importance of OM characterization in SPM in order to better assess to the spatial and temporal OM variations in the water column.

Keywords: Suspended Particulate Matter, Moselle River, Particulate Organic Matter, Molecular Characterization

\section{Introduction}

Rivers transport large amounts of organic matter (OM), from the terrestrial environment to the seas. In the river, OM can be transported in both dissolved (DOM or dissolved organic carbon, DOC) and particulate forms (POC or POM). It is estimated that $0.4 \mathrm{Gt} / \mathrm{yr}$ is exported by rivers to the oceans and the amount in particulate form is estimated to $0.17 \mathrm{Gt}$ (Ludwig et al., 1996; Cole et al., 2007). The OM in aquatic systems is composed of a wide variety of complex compounds, resulting from the diversity of the natural processes of synthesis and degradation. One method used to classify $\mathrm{OM}$ is to separate the allochthonous $\mathrm{OM}$ from the autochthonous OM (Filella, 2009). The autochthonous OM is formed exclusively in the water column and is composed of the residues of phytoplankton, algae and aquatic bacteria (Wetzel, 
2001). In natural aquatic media or in aquatic media with low anthropogenic input, the allochthonous OM results mainly from the degradation of higher plants by bacteria and fungi and is transferred from soils to rivers by rainwater (Filella, 2009). However, in most European rivers, the allochthonous OM might also result from human activity and could originate from domestic or industrial wastewater, via urban surface run-off (Micić et al., 2011). In rivers with high anthropogenic pressure, the industrial input and domestic input bring organic and mineral micropollutants from which polycyclic aromatic hydrocarbons (PAHs) are an important and commonly studied family (Jeanneau et al., 2006; Qiao et al., 2014). Because the PAHs are sorbed on suspended particulate matter (SPM) and due to their low water solubility, they are rather well preserved in aquatic media (Punning et al., 2008). Then, they constitute relevant organic markers, particularly for an anthropogenic input.

One way to investigate the composition of $\mathrm{OM}$ in aquatic media and distinguish between the sources is the use of pyrolysis in combination with gas chromatography and mass spectrometry (Py-GC-MS). This technique, based on separation, has the advantage to identify the pyrolysis products of molecular markers, such as lignins, carbohydrates and fatty acids (FAs), permitting characterization of different organic contributions to soils, sediments, suspended matter and water (Grasset et al., 2009; Micic et al., 2011; Bertrand et al., 2013; Jeanneau et al., 2014). A classical analysis for deciphering the different inputs of OM to the water column consists of measurements of molecular-level lignin, either by extraction using cupric acid oxidation or by thermochemolysis-GC-MS (TMH-GC-MS) (e.g. Hernes et al., 2008; Frazier et al., 2003). The characteristics of these compounds can inform on the land use, and nature of crops or on the OM degradation and can also permit the differentiation between allochthonous and autochthonous sources (Dalzell et al., 2005; Hernes et al., 2008). In particular cases, especially for small watersheds (a few $\mathrm{km}^{2}$ ), such studies of lignin can decipher contributions from soil erosion and from river bank erosion (Jeanneau et al., 2014). 
Most studies of lignin phenols concern DOM and some others deal with the molecular analysis of lignin compounds within suspended matter (POM; Ward et al., 2015; Bianchi et al., 2007). Other compounds can also be studied in order to unravel the composition of the OM. For example, carbohydrates such as fucose can be used to reveal a microbial contribution as fucose is rarely encountered in vascular plant (Jeanneau et al., 2014, Grasset et al., 2009). The analysis of the lipid extract by way of GC-MS is a second means of performing source apportionment. Boëchat et al. (2014) used lipidic fatty acids (Lip-FAs) in order to evaluate the influence of human activity and land use on OM composition. They found that, downstream of large cities, the Lip-FAs distribution was dominated by palmitic $\left(\mathrm{C}_{16: 0}\right)$ and stearic $\left(\mathrm{C}_{18: 0}\right)$ acids. These compounds were described as FAs from treated and raw sewage (Quéméneur and Marty, 1994; Réveillé et al., 2003). In a more extended study of POM composition, Medeiros et al. (2012) showed the variation along the Mullica River (NJ, USA). Upstream, terrestrial markers from higher plants were predominant and sharply decreased downstream and were replaced by microbial markers. During high flow, significant amounts of upstream markers were found downstream, revealing the downstream transport of terrestrial material. Most studies concerning molecular scale investigation of $\mathrm{OM}$ in rivers focus on DOM. However, in aquatic media, POM acts as a carrier of pollutants, such as metals (Bibby et Webster-Brown, 2006; Hua et al., 2012) or organic chemicals (Ni et al., 2008), especially hydrophobic contaminants (Luo et al., 2009). POM also regulates aquatic metabolism (Cole, 2013) and can act as a ligand for particle aggregation (Lartiges et al., 2001). The few studies about POM generally focus on one single molecular group and most of the time deal with spatial considerations rather than temporal variations. Furthermore, the multi-molecular investigation of OM composition is performed mainly on small streams. For example, Medeiros et al. (2008) studied rivers with seasonal mean discharge ranging between 0.5 and $38 \mathrm{~m}^{3} / \mathrm{s}$. 
This work aims at better understand the spatial and temporal variations of molecular OM in SPM from a relatively large watershed $\left(11,500 \mathrm{~km}^{2}\right)$. The spatial $\mathrm{OM}$ composition was investigated using different stations along the Moselle River and four tributaries. The different stations have different land use and the goal was to better understand the effects of land use on OM composition. The temporal variations were investigated using an anchor station sampled several times during different seasons and regime flow. The aims were to test the influence of different hydrologic and climatic conditions on the molecular $\mathrm{OM}$ composition in SPM. This work complements a previous study (Le Meur et al., 2015) where the SPM was fully characterized in terms of mineralogy and grain size distribution. Mineralogical markers demonstrated that SPM were rather homogeneous along the Moselle River, with no drastic variations from one station to another, and suggested that soil erosion was the main source of particles. Hydrological conditions were shown to play a stronger influence on elemental composition of SPM.

\section{Material and methods}

\subsection{Study site}

The study is located in the Moselle catchment in the northeastern France (Fig. 1; see also Le Meur et al., 2015). The mean annual temperature is $10^{\circ} \mathrm{C}$ and the mean annual precipitation is $775 \mathrm{~mm}$. The Moselle watershed land use is heterogeneous with urban, cultivated and natural areas (Fig. 1 and Table 1). In order to evaluate the land use effect on the POM composition, we selected 10 stations along the Moselle River and four of its tributaries. These stations were selected on the basis of the land use. Fig. 1 and Table 1 show the urbanized parts of the Moselle catchment, using the Corine Land Cover layer (Corine Land Cover, 2006) and more details about the stations are provided in Le Meur et al. (2015). Among the 10 stations, Frouard (FRO) was selected as the anchor station to follow the water flow (Appendix A1) and seasonal variations in SPM properties. This station was selected due to the proximity to the 
laboratory and the easy access to the river. On the Moselle River, the urbanization area is rather uniform (Table 1), with values ranging from $4.2-4.9 \%$ from the most upstream station Flavigny (FLA) and the most downstream station Thionville (THI). Among the stations, we considered that the station on the Fensch River (FLO in Florange) was a reference for a highly urbanized stream, due to the high proportion of urbanized areas $(33 \%)$. The high level of contamination of Fensch water was reported in previous studies (Jeanneau et al., 2006, 2008; Montarges-Pelletier et al., 2007) and is due to the past industrial activity on one part and to the occurrence of direct wastewater input on the other.

\subsection{Sampling procedure}

SPM samples were collected between October 2012 and March 2015 (Table 2). For the collection of SPM, river water was pumped and sent to a continuous flow field centrifuge (CEPA Z-41 20000 RPM, equivalent $17000 \mathrm{~g}$ ). The flow rate was set to $600 \mathrm{l} / \mathrm{h}$. In order to collect high amounts of SPM (between 7 and $70 \mathrm{~g}$ of dried sample, depending on water turbidity), the centrifuge was run between 2 and $4 \mathrm{~h}$ for a given sampling campaign. The performance was checked during the whole sampling operation by measuring turbidity and grain size distribution of the raw water entering the centrifuge bowl and the exiting waters.

The size cut-off of retained particles was approximate $3 \mu \mathrm{m}$ and was checked with laser diffraction analysis of the centrifuge input and output at different times during the sampling procedure (Laser diffractometer SYMPATEC).

SPM samples were gently recovered from the Teflon plates covering the internal surface of the centrifuge bowl, and immediately frozen and freeze dried. The SPM content of the water column (mg/l) was also determined by filtering river water (100 to $1000 \mathrm{ml}$ ) through $0.22 \mu \mathrm{m}$ Millipore (C) nitrocellulose membranes (weighed before use). Filters were oven dried $\left(40{ }^{\circ} \mathrm{C}\right)$ overnight. SPM content was determined from the difference in weight. Three filter membranes were prepared for each water sample. The samples were selectively measured on 
the basis of the land use properties at the station or the regime flow during the sampling.

\subsection{Thermal analysis, OM content, Thermogravimetry $(T G)$ and differential scanning} calorimetry (DSC)

Thermal analysis was performed using differential scanning calorimetry (TG-DSC; Setaram Labsys Evo 1600) at the SOLEIL facilities (Gif sur Yvette, France). Samples (30 mg) were placed in an alumina crucible with an identical and empty crucible used as the reference, and heated from ambient to $1000{ }^{\circ} \mathrm{C}$ at $5{ }^{\circ} \mathrm{C} / \mathrm{min}$ under an oxidizing atmosphere (flow rate 20 $\mathrm{ml} / \mathrm{min})$ of synthetic air $\left(20 \% \mathrm{O}_{2}\right.$ and $\mathrm{N}_{2}$ balance). The data heat flow was corrected from the data of the standard measurement (measurement without sample).

\subsection{Organic molecular characterization}

Lipidic OM was extracted using dichloromethane (DCM) with an automatic extractor (Dionex ASE 350) at $100{ }^{\circ} \mathrm{C}$ and $10^{6} \mathrm{~Pa}$. In order to avoid spectrometer damage due to the presence of elemental S, it was removed by the addition of metallic $\mathrm{Cu}$. The insoluble fraction was analyzed using TMH-GC-MS with tetramethylammonium hydroxide (TMAH). This method is suitable in order to investigate the molecular $\mathrm{OM}$ and, in particular, the tracers utilized to separate terrestrial versus aquatic inputs (Frasier et al., 2003; Jeanneau et al., 2014). The solvent-extracted SPM was mixed with solid TMAH in excess (1:5\% wt.; Hatcher and Clifford, 1994). An aliquot (10-15 mg) was placed into a quartz tube and TMH-GC-MS (Hewlett Packard 6890-Hewlett Packard 5972) analysis carried out using a split/splitless injector. On-line flash pyrolysis at $620^{\circ} \mathrm{C}$ was performed with a CDS 2000 Pyroprobe for 15

s. Pyrolysis products were separated on a DB 5-MS $60 \mathrm{~m}$ x $0.25 \mathrm{~mm}$ x $0.1 \mu \mathrm{m}$ column. Samples were injected in splitless mode at $300{ }^{\circ} \mathrm{C}$. The oven was cooled to $0{ }^{\circ} \mathrm{C}$ (held 0.5 
min) by injecting liquid $\mathrm{CO}_{2}$ and was programmed to $40{ }^{\circ} \mathrm{C}$ (held $10 \mathrm{~min}$ ) at $45{ }^{\circ} \mathrm{C} / \mathrm{min}$, then to $315{ }^{\circ} \mathrm{C}$ (held $10.5 \mathrm{~min}$ ) at $5{ }^{\circ} \mathrm{C} / \mathrm{min}$. Pyrolysis products were identified from GC retention times and mass spectra from comparison with the Wiley mass spectral library. Assignments were also carried out from comparison with published mass spectra of pyrolysis products (Challinor, 1995; Mason et al., 2012). A semi-quantification was applied for each sample. The peak area of the selected $\mathrm{m} / \mathrm{z}$ value for each compound was integrated and corrected via a correction factor. The proportion of each compound class was calculated by dividing the sum of the areas of the compounds in the class by the sum of the peak areas of all analyzed compounds multiplied by 100 . Eight lignin phenols were selected to describe the lignin composition, and six permethylated deoxy aldonic acids (glucose, mannose, galactose, xylose, rhamnose and fucose) to describe oses. The distribution of the Fatty acids in the refractory fraction (Ref-FAs) was also used (from n- $\mathrm{C}_{6}$ to $\mathrm{n}-\mathrm{C}_{26}$ ).

The extracts were also analyzed with GC-MS for Lip-FAs, PAHs and sterols. Only the PAHs were quantified using internal standards and were analyzed separately. Four perdeuterated PAHs were added to each extract (naphthalene $D_{8}$, acenaphthene $D_{10}$, chrysene $D_{12}$, perylene $\mathrm{D}_{12}$ ). In addition, four oxygenated-PAHs (O-PAHs) and nitrogenous-PAHs (N-PACs) were added (quinolone D7, anthraquinone D8, dibenzofuran D, 9Hand fluorenone D8). PAHs are expressed in $\mu \mathrm{g} / \mathrm{g}$ dry SPM. PAHs quantification was performed using a Shimadsu-2010 plusQP2010 Ultra. This apparatus is equipped with a DB 5-MS column (60 m x $0.25 \mathrm{~mm}$ x 0.1 $\mu \mathrm{m})$ and operated in selected ion monitoring (SIM) mode. Samples were injected in split mode (split ratio $1: 5$ ) at $300{ }^{\circ} \mathrm{C}$. The GC oven temperature was programmed from $70{ }^{\circ} \mathrm{C}$ (held $2 \mathrm{~min}$ ) to $130{ }^{\circ} \mathrm{C}$ at $15^{\circ} \mathrm{C} / \mathrm{min}$, then from $130{ }^{\circ} \mathrm{C}$ to $315^{\circ} \mathrm{C}$ (held $2 \mathrm{~min}$ ) at $4{ }^{\circ} \mathrm{C} / \mathrm{min}$.

Sterols and Lip-FAs were analyzed qualitatively after derivatization using N,Obis(trimethylsilyl)trifluoroacetamide (BSTFA)/trimethylchlorosilane (TMCS). Sterols and Lip-FAs were characterized using an Agilent GC7820/MS75. This apparatus was equipped 
with a DB 5-MS column (60 $\mathrm{m} \times 0.25 \mathrm{~mm} \times 0.25 \mu \mathrm{m})$ and operated in selected ion monitoring (SIM) mode. Samples were injected in split mode (split ratio 1:5) at $300{ }^{\circ} \mathrm{C}$. The GC oven temperature was programmed from $70{ }^{\circ} \mathrm{C}$ (held $2 \mathrm{~min}$ ) to $130{ }^{\circ} \mathrm{C}$ at $15^{\circ} \mathrm{C} / \mathrm{min}$, then from $130{ }^{\circ} \mathrm{C}$ to $315^{\circ} \mathrm{C}$ (held $2 \mathrm{~min}$ ) at $4{ }^{\circ} \mathrm{C} / \mathrm{min}$.

\section{Results}

3.1 Thermal analysis, OM content, Thermogravimetry $(T G)$ and differential scanning calorimetry (DSC)

The OM content of SPM was estimated from differential scanning calorimetry curves and thermal gravimetry curves (Appendix A2). In the $180-460{ }^{\circ} \mathrm{C}$ range, weight loss is essentially due to the exothermic combustion of $\mathrm{OM}$. The content of $\mathrm{OM}$ varied from $6 \%$ to $12.6 \%$, except for SPM from the FLO station which contained 22\% (Appendix A2). The values were plotted against water discharge (Fig. 2) and showed a slight decrease with increase of water level. The decrease could be explained by the relative increase in lithogenic contribution to the SPM (see also Le Meur et al., 2015). The Total Organic Carbon (TOC) was also measured and the detailed results are presented in Le Meur et al. (2015). TOC values at FRO station also showed relative decrease with increase of the regime flow except for the highest regime flow (Appendix A3).

\subsection{Macromolecular investigations}

3.2.1. Fatty acids in the refractory fraction (Ref-FAs)

Fig. 3 displays the fatty acids distribution in the refractory fraction (Ref-FAs) for four samples collected in the same time period (November 2012), with similar regime flow. From upstream to downstream, the selected stations were Flavigny (FLA), Frouard (FRO) and Pont- 
à-Mousson (PAM). The distribution obtained for FLO sample (our urban reference) was also plotted. The Fig. 3 shows that the distributions in these SPM samples were similar from one sample to another. Indeed, $n-\mathrm{C}_{6}$ to $n-\mathrm{C}_{26}$ alkanoic acids were observed in all the samples and showed a strong even/odd carbon number predominance. The composition was clearly dominated by palmitic acid $\left(\mathrm{C}_{16: 0}\right)$ and stearic acid $\left(\mathrm{C}_{18: 0}\right)$. However, slight variation could be observed from one station to another. At the downstream station PAM, palmitic acid and stearic acid appeared relatively more abundant, whereas their respective contributions appeared weakened for the most upstream station at Flavigny. SPM sample collected in Florange (FLO, Fensch River), displayed a relatively higher contribution for $\mathrm{C}_{16: 1}, \mathrm{C}_{18: 1 \omega 7}$ and $\mathrm{C}_{18: 1 \omega 9}$ (oleic acid) (Fig. 3). Due to the highly urbanized context, and the occurrence of several dozen examples of direct wastewater input to the Fensch River ${ }^{1}$, the Florange sample was expected to display a drastically different fingerprint. However, the distribution in Fig. 3 shows an FA profile rather close to those of the Moselle SPM. The main differences occurred for $\mathrm{C}_{16: 1}, \mathrm{C}_{18: 1 \omega 7}$ and $\mathrm{C}_{18: 1 \omega 9}$. Sewage water or domestic water can be fingerprinted by the presence of branched iso (i) and anteiso (a) $\mathrm{C}_{15: 0}$ - acids and also $\mathrm{C}_{16: 1}$ (Jardé et al., 2007). Only $\mathrm{C}_{16: 1}$ could be observed with a higher contribution reflecting the bacterial contribution in FLO sample. The FRO station was sampled several times with different regime flows and seasons. The FA distribution displayed the predominance of palmitic and stearic acids similar to other stations. The SPM sampled during the summer low flow season (FRO jun13 $35 \mathrm{~m}^{3} \cdot \mathrm{s}^{-1}$ and FRO jul13 $15 \mathrm{~m}^{3} \cdot \mathrm{s}^{-1}$ ) showed higher contribution of $\mathrm{C}_{16: 1}$ (Table 3).

\subsubsection{Permethylated deoxy aldonic acids derived from carbohydrates}

\footnotetext{
${ }^{1}$ Personal communication from A. Fall, in charge of Hydrology department of the CAVF (Fensch Valley cities network, communauté d'agglomération du Val de Fensch)
} 
251

252

253

254

255

256

257

258

259

260

261

262

263

264

Series of permethylated deoxy aldonic acids in the pyrolysis products of all samples from the Moselle catchment were assigned on the basis of the predominant $m / z 129$ fragment in the mass spectra. These compounds are derived from carbohydrates (Fabbri et al., 1996; Mason et al., 2012) and are formed from the degradation of the glucose, galactose, xylose, rhamnose and fucose during the pyrolysis with TMAH. In all the samples, the most abundant compound was glucose, followed by galactose, xylose, rhamnose and fucose. These five permethylated deoxy aldonic acids are present in different proportions in the living organisms and can be used to differentiate sources (Grasset et al., 2009). Glucose is present in most of living organisms and at a higher level in vascular plants (Grasset et al., 2009). Mannose is present in higher proportion in gymnosperms than angiosperms (Cowie and Hedges, 1984). Conversely, xylose is produced in higher proportion by angiosperms than by gymnosperms (Wicks et al., 1991). Fucose is rarely observed in vascular plants but is present in higher proportion in some bacteria (Cowie and Hedges, 1984). The deoxy $\mathrm{C}_{6} / \mathrm{C}_{5}$ ratio (rhamnose+fucose)/(xylose arabinose) was defined in order to detect any variation in carbohydrate variations with regime flow or seasons and with different stations (Table 3).

Concerning spatial variability, the ratio did not show a clear trend. At FRO, we observed a slight increase during the summer low flow period. Jeanneau et al. (2014) observed evolution of the ratio with DOC. They showed that DOC was clearly higher than observed for our SPM. They also showed that DOC was between 0.4 and 0.2 in the soils, which is close to the ratio in our SPM.

\subsubsection{Lignin-derived compounds}

Like the Ref-FAs and polysaccharides, the thermochemolysis of the SPM produced a series of lignin-derived methylated monomers. These phenol compounds were semi-quantified and were sorted in three groups, vanillyl, syringyl and cinnamyl. From these compounds we can 
separate the different plant tissues. Gymnosperm woody tissue contains mainly V units $(80 \%)$ with $\mathrm{C}$ units whereas angiosperm woody tissues are characterized by $\mathrm{V}$ an $\mathrm{S}$ units in the same proportion with C units (Clifford et al., 1995; Challinor, 2001). Non woody tissues (grass, leaves, needles, stems) have V, C and S units in the same proportion. Several studies using $\mathrm{CuO}$ oxidation showed that the use of ratios such as $\mathrm{C} / \mathrm{V}$ and $\mathrm{S} / \mathrm{V}$ can permit the identification of terrestrial inputs (Hedges and Mann, 1979; Hedge et al., 1982). However, Clifford et al. (1995) also showed that the TMAH thermochemolysis can provide similar results without quantification using robust ratios. The ratio cinnamyl/vanillyl (C/V) was calculated following Hedges and Mann (1979). C/V is consistently higher in macrophyte and grass-derived plant tissue relative to woody tissue, making it a useful ratio for differentiating between the different vegetation types in a watershed. Table 3 shows $\mathrm{C} / \mathrm{V}$ for all the SPM samples in the Moselle watershed. For the samples Flavigny, Frouard NOV12 and Pont-à-Mousson NOV12, which were sampled in the same range of regime flow, $\mathrm{C} / \mathrm{V}$ was higher at Flavigny $(0.58)$ than at Frouard (0.44). The value at Pont-à-Mousson was 0.49 . The Richemont station showed high $\mathrm{C} / \mathrm{V}$ ratio (1.12). The values of $\mathrm{C} / \mathrm{V}$ ratio also showed a slight decrease with increase in regime flow for Frouard samples except for FRO nov13 (C/V $=0.68)$. Supplementary ratios were used to investigate the oxidative diagenesis of lignin. Indeed, the degradation of lignin compounds can be inferred from an increase in total acid phenols relative to the total aldehyde phenols (syringic acid to syringaldehyde ( $\mathrm{Ad} / \mathrm{Al}(\mathrm{s}))$ and vanillic acid to vanillin $(\mathrm{Ad} / \mathrm{Al}(\mathrm{v}))$ ratios). The work of Hedges et al. (1982) showed that high values of these ratios can be explained by a degradation of lignin. $\mathrm{Ad} / \mathrm{Al}_{(\mathrm{v})}$ in the watershed varied between 1.36 and 2.96 (Table 3), indicating different states of lignin degradation. In the Moselle River, for SPM collected at Frouard, $\mathrm{Ad} / \mathrm{Al}_{(\mathrm{v})}$ slightly increased with water discharge, suggesting a contribution from more degraded lignin during flood events. Looking at the spatial variability, the SPM collected from the Madon and Meurthe Rivers, respectively at the 
302

303

304

305

306

307

308

309

310

311

312

313

314

315

316

317

PSV and BOU stations, displayed lower values for the ratio, suggesting that the lignin degradation could be influenced by the Strahler order of the stream and/or by the land use.

\subsection{Lipid fraction}

3.3.1 Fatty acids in the lipid fraction (Lip-FAs)

Fig. 4 shows the fatty acid distributions in the lipid fraction (Lip-FAs) for samples collected in November 2012 (FLA, FRO and PAM), and also for FLO. The distributions in the selected SPM samples were very similar to those in the refractory fraction. In this fraction again, the FAs were dominated by palmitic acid $\left(\mathrm{C}_{16: 0}\right)$ and stearic acid $\left(\mathrm{C}_{18: 0}\right)$. However, we could observe $n-\mathrm{C}_{6}$ to $\mathrm{n}-\mathrm{C}_{32}$ alkanoic acids with a strong even predominance. Slight variation in distribution could also be observed from one station to another. $\mathrm{C}_{18: 1 \mathrm{w} 7}$ was observed for the three stations on Moselle River but was not detected at FLO station. For the FLA and PAM stations, the $\mathrm{C}_{20: 0}$ to $\mathrm{C}_{32: 0}$ compounds were more represented than for the FRO and FLO stations. In addition, the Terrigenous/Aquatic Ratio (TAR) $\left(\mathrm{C}_{28}+\mathrm{C}_{26}+\mathrm{C}_{24}\right) /\left(\mathrm{C}_{18}+\mathrm{C}_{16}+\mathrm{C}_{14}\right)$ was higher for PAM (0.23) and FLA (0.24) than for FRO (0.01) and FLO (0.03), reflecting the higher contribution of terrestrial compounds at FLA and PAM. FLA station also displayed higher $\mathrm{C}_{16: 1}$ contribution (Table 4). FRO jul13 also shows higher $\mathrm{C}_{16: 1} / \mathrm{C}_{16: 0}$ ratio.

\subsubsection{Sterol composition}

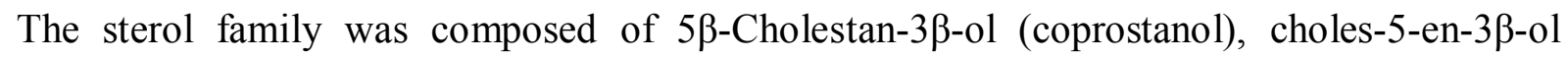
(cholesterol), 24-ethylcholest-5-en-3 $\beta$-ol (sitosterol), 24-ethyl-5 $\beta$ cholestan-3 $\alpha$-ol

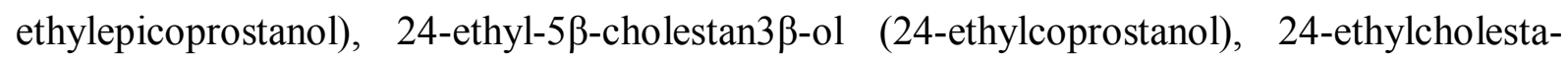
5.22E-dien-3 $\beta$-ol (stigmasterol), 24-Methylcholest-5-en-3 $\beta$-ol (campesterol), 24-ethyl-5 $\alpha$ - 


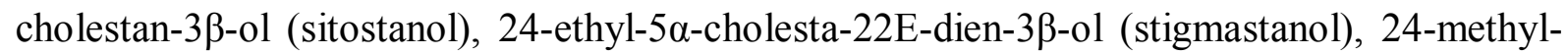

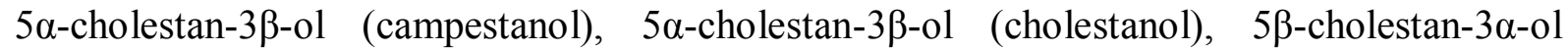
(epicoprostanol). Fig. 5 shows the sterol distribution in the Moselle and Fensch samples. Among the twelve sterols in the SPM samples, coprostanol and cholesterol dominated. Coprostanol comes mainly from the degradation of cholesterol by bacterial activity in the digestive system of sheep, cattle, pigs, cats and humans (Leeming et al., 1996) and is the main sterol in human feces $(60 \%$ of the steroids, MacDonald et al., 1983) and so is often used as a waste water treatment plant (WWTP) marker (Hatcher and McGillivary, 1979). Cholesterol is a ubiquitous compound and can be encountered in both plant and animal kingdoms.

Different ratios can be used to identify any contamination in river waters. For example, values of coprostanol/cholesterol (Cop/Chol) $>0.5$ are characteristic of human feces (Grimalt et al., 1990; Fattore et al., 1996; Reeves and Patton, 2005). In the Moselle catchment, the values obtained varied between 0.2 and 2.94. In most cases, the value was $>0.5$, indicating the high contribution of coprostanol (Table 4). During summer and low flow regime (FRO JUN13, FRO JUL13, $35 \mathrm{~m}^{3} \cdot \mathrm{s}^{-1}$ and $15 \mathrm{~m}^{3} \cdot \mathrm{s}^{-1}$ respectively), Cop/Chol ratio was low, showing a strong terrestrial and/or an autochthonous contribution of sterols. Cop/Chol increased with flow regime, indicating that waste water was directly discharged into the Moselle River or the lower autochthonous OM contribution. Only two samples (FRO-jun13 and FRO-jul13) showed values of 0.2. FLO station displayed the highest Cop/Chol ratio (2.9). This value could be related to the WWTP located upstream of the sampling site on the Fensch River. The ratio was also high at BOU (2.4), PAM (2.9) and FRO (2.58 for November 12). BOU and PAM stations are downstream of the WWTP of Nancy and Pont-à-Mousson cities respectively.

The (stigmastanol+sitostanol+stigmasterol+sitosterol)/(cholesterol+cholestenol) ratio $\left(\mathrm{C}_{29} / \mathrm{C}_{27}\right.$ (ST) $)$ can also be used in order to evaluate the proportion of allochthonous and 
353

354

355

356

357

358

359

360

361

362

autochthonous OM (Nishimura and Koyama, 1977). Higher plants synthesize a $\mathrm{C}_{29}$ sterol, $\beta$ sitosterol (Huang and Meinschein, 1976). This compound can also be encountered in phytoplankton and notably in diatoms (Volkman, 1986, 2003). In contrast, $\mathrm{C}_{27}$ sterols have essentially an aquatic origin (Huang and Meinschein, 1976). The values of $C_{29} / C_{27}$ (ST) increased with regime flow, indicating higher $\mathrm{C}_{29}$ contribution or lower $\mathrm{C}_{27}$ contribution (Table 4) and inform on the higher autochthonous OM during high flow regime. The high flow regimes SPM were sampled during the winter. In these winter samples, few diatoms were observed (Le Meur et al., 2015). In addition, brassicasterol and 24-methylenecholesterol were not observed in our samples. These sterols are typical sterols encountered in diatoms. The $\mathrm{C}_{29}$ should have a terrestrial origin in our SPM during the winter storm event samples or at least the decrease of autochthonous OM contribution.

\subsubsection{PAHs composition}

The 16 PAHs listed by the US Environmental Protection Agency (EPA) were quantified and some ratios calculated to provide an overview of the PAHs contamination through the catchment (Table 5). The sum of 8 PAHs concentrations in the SPM from Moselle catchment ranged between 2.3 and $7.7 \mu \mathrm{g} / \mathrm{g}$. All the samples displayed lower 8 PAHs concentrations than the regulatory value of $8.649 \mu \mathrm{g} / \mathrm{g}$ defined by the European legislation (recommended concentration to evaluate the quality of sediments and SPM in continental waters). The PAHs in SPM were dominated by heavy aromatic hydrocarbons (HMW-PAHs) from fluoranthene (Flt) to benzo(ghi)perylene (Bghi) (Table 5 and supplementary information 4). Indeed, the contribution of 4 to 6 ring PAHs accounted for 69 to $91 \%$ of the total PAHs concentration. The dominant PAHs at all the stations was fluoranthene. The sum of 16 PAHs quantified in the SPM did not show clear spatial trends in the Moselle catchment. No clear increase in PAHs content could be observed for samples collected in the vicinity of highly urbanized areas (FLO station for example) and also for FRO samples collected during different regime 
flow $(2.9$ to $5.1 \mu \mathrm{g} / \mathrm{g})$. Several ratios were tested to evaluate their variation in the catchment. The An/178 ratio (anthracene/(anthracene+phenanthrene)) (Budzinski et al. 1997), the $\mathrm{BaA} / 228$ ratio (benzo(a)anthracene/(benzo(a)anthracene+chrysene)) and the $\mathrm{Fl} / 202$ ratio (fluoranthene/(fluoranthene+pyrene)) (Yunker et al., 2002) are usually used to distinguish between petrogenic and pyrogenic inputs. Through the Moselle catchment BaA/228 varied between 0.53 and 0.58 (except for MIL 0.40 and FRO oct13 1.00) and was constant spatially and temporally. F1/202 ratio also showed constancy, with values ranging from 0.54 to 0.59 , except for FRO oct13 for which the value was 0.43 and for MIL (0.75). An/178 showed wider variation, with values ranging from 0.29 to 0.55 . However, the variations did not show clear trend. The three ratios were rather stable along the Moselle catchment and with regime flow and highlighted the idea that PAH content in the SPM did not vary spatially and temporally. Thus, the quantification of PAHs in SPM is a useful tool for evaluating the anthropogenic pollution and for comparing catchments with a surface area of similar order. The OxygenatedPACs (O-PACs) and nitrogenous-PACs (N-PACs) were also quantified in the SPM and the results are presented in the supplementary data (Appendix A4) as there was no clear trend between the stations, regime flow or seasons.

\section{Discussion}

\subsection{Spatial Variability in OM composition, influence of land use}

One of the goals of this study was to evaluate the sensitivity of OM markers in order to trace variations along the Moselle River. The Moselle watershed is characterized by the evolution of land use through the catchment (Table 1). Consequently, the OM markers were expected to vary through the catchment. One station, FLO station, showed variations of the molecular OM composition. This station showed higher relative contribution of $\mathrm{C}_{16: 1}, \mathrm{C}_{18: 1 \mathrm{w} 7}, \mathrm{C}_{18: 1 \mathrm{w} 9}$ for the Ref-FAs and $\mathrm{C}_{16: 1}$ is one of the compounds characteristic of sewage water (Jarde et al., 2007). 
Other compounds such as coprostanol was also higher. Such higher contribution was expected, as this station on the Fensch River is characterized by high anthropogenic pressure in this small watershed (Jeanneau et al., 2006, 2008; Montarges-Pelletier et al., 2007, 2014). The mineral composition at Florange station is also impacted by the anthropogenic pressure with, in particular, the presence in high proportion of iron oxyhydroxides and trace metals such as lead and Zinc (Le Meur et al., 2015). The FLA station, which is the most upstream station sampled, also showed a significant contribution of anthropogenic markers such as $\mathrm{C}_{16: 1}$ and coprostanol besides the low urban area (6\%). A domestic water contribution was also expected at this station, located in the Flavigny city. However, the Lip-FAs showed a high contribution from $\mathrm{C}_{24: 0}$ to $\mathrm{C}_{30: 0}$ and TAR ratio was also low. These observations reflect a relatively high terrestrial contribution as these compounds are believed to be components of higher plants wax (Rieley et al., 1991; Meyers, 2003).

The family of compounds corresponding to lignin derivatives also did not show a clear evolution along the course of the Moselle except for Richemont station. SPM from RIC station displayed $\mathrm{C} / \mathrm{V}$ values higher than for the other samples (Table 3). This higher ratio could be related to the higher proportion of cultivated areas for the Orne watershed $(67 \%)$. Some other studies have reported variation of C/V for the Mississippi River (Bianchi et al., 2007) and the Amazon River (Ward et al., 2015). However, in these large rivers, the quantity of exported $\mathrm{OM}$ is high and explains the variation in lignin composition. In order to decipher any variation in $\mathrm{C} / \mathrm{V}$ through the Moselle watershed, it would be necessary to take into account the regime flow of the river and also report on the OM productivity and exportation. The degradation state of lignin, observed through the $\mathrm{Ad} / \mathrm{Al}_{(\mathrm{v})}$ ratio showed more preserved lignin in the Madon and Meurthe Rivers. The lignin degradation could thus be affected by the Strahler order of the stream or the land use. 
Other compounds such as PAHs did not show a clear trend in the Moselle catchment, with relatively low variation in the sum of the 8 PAHs and low variation in the different ratios calculated (An/178; BaA/228; Fl/202). This relative homogeneity could be a result of the global atmospheric pollution and its deposition as particles in the river. For Tianjin River, the absence of a trend between upstream and downstream stations was also reported by Shi et al. (2005). They found better spatial relationships in sediments with greater contamination close to industrialized areas. SPM from Tianjin River were also enriched in HMW PAHs $(32 \%$ of total PAHs; Shi et al., 2005). Because they are more hydrophobic, HMW PAHs would more likely enter in the river in particulate form from soil run off or atmospheric deposition (Countway et al., 2003).

The characteristics of POM did not vary through the catchment and only smaller subcatchments (e.g. Fensch) showed variation in relation with the extensive industrialization and urbanization. This similarity in composition could be the result of the size of the Moselle catchment, as it drains $>10,000 \mathrm{~km}^{2}$. The other explanation could come from the POM itself that appears to be more integrative than DOM. The mineral characterization of Moselle SPM also showed a relative homogeneity, with variations only encountered at Florange and Richemont (Le Meur et al., 2015).

\subsection{Temporal variability of OM composition, influence of season and hydrological conditions}

The other aim of this study was to decipher any variation in the OM composition with seasonality (mainly driven by temperature) and/or regime flow of the Moselle River. During low flow regimes at the FRO station, where the temperature was high, the samples were characterized by a higher deoxy $\mathrm{C} 6 / \mathrm{C} 5$ ratio which indicates microbial contribution (Rumpel and Dignac, 2006). In addition, the number of diatoms during summer low flow regime is high (Le Meur et al., 2015). The $\mathrm{C}_{16: 1} / \mathrm{C}_{16: 0}$ ratio is also high and monounsaturated FAs are major components of freshwater algae and bacteria (Cranwell, 1974, 1982; Volkman et al., 
477 with regime flow or with temperatures. level with high temperatures.

1980). In addition the total OM content is high and the OM is relatively unaltered (low $\mathrm{Ad} / \mathrm{Al}_{(\mathrm{v})}$ ratio). All these markers encountered in the extract and in the macromolecular $\mathrm{OM}$ are in accordance with an enhancement of autochthonous OM during the summer low flow

The increase in regime flow, sampled during the winter storm period involved a decrease in the markers cited above, which can be assigned to a greater contribution of allochthonous OM and/or by rapid degradation of OM. A clear decrease in POM content was also observed (Fig. 2). This can be assigned on one hand to the decrease in autochthonous $\mathrm{OM}$ as its production is high in warm seasons and its contribution to POM dominates at low flow periods. On the other hand, during high flow periods, allochthonous POM dominates. It can be assumed, that intense rain events provoke the contribution from subsurface soil horizons (a few $\mathrm{cm}$ ), containing a lower amount of OM, or displaying higher degree of mineralization of OM (also see Le Meur et al., 2015). In addition, $\mathrm{C} / \mathrm{V}$ ratio and $\mathrm{Ad} / \mathrm{Al}_{(\mathrm{v})}$ indicated more degraded lignin during high flow level (Fig. 6). Another explanation could be the remobilization of sediments in the water column. Other studies have shown variation in DOM composition, with less degraded lignin mobilized during high flow level in small catchments (few $\mathrm{km}^{2}$; Dalzell et al., 2005; Hernes et al., 2008; Jeanneau et al., 2014). In their review, Marin-Spiotta et al. (2014) show that, during low flow, the DOM in the water column resembles deep OM from soil, whereas, during high flow, the DOM resembles surface soil DOM, suggesting different pathways during high and low water flow. Our results suggest that POM transfer from soil to river in a large catchment would not follow the same path as DOM. As for the spatial distribution, the PAHs content of SPM ( $\Sigma 16$ PAHs and $\Sigma 8 \mathrm{PAHs})$ does not show a clear trend 


\section{Conclusions}

Molecular analyses of POM were performed in the Moselle catchment at different stations and during different flow regimes and seasons. Due to contrasted land use from upstream to downstream the Moselle watershed, SPM OM composition was expected to evolve. However, the OM composition was rather similar at the Moselle, Meurthe and Madon stations. Only one station, the FLO station, displayed variations in the POM chemistry with higher relative contribution of $\mathrm{C}_{16: 1}$ and coprostanol which are indicators of microbial contribution and sewage water. The Meurthe and Madon tributaries showed more preserved lignin through the $\mathrm{Ad} / \mathrm{Al}_{(\mathrm{v})}$ ratio. This observation suggest that the Strahler order of the stream or the land use can affect the lignin degradation. The PAHs showed slight variation through the catchment, highlighting the fact that a catchment of this size is integrative. This similarity can also come from the integrative status of the POM itself. SPM OM composition was also followed as a function of flow regime and seasons at FRO station. The increase of the limb of the hydrograph resulted in a decrease of OM content in SPM. In addition, the different lignin indicators $\left(\mathrm{C} / \mathrm{V}\right.$ and $\mathrm{Ad} / \mathrm{Al}_{(\mathrm{v})}$ ratios) revealed the presence of more degraded lignin at FRO station during high flow regime. These results could be explained by the higher contribution of allochthonous OM coming from the subsurface soil leaching or by the surface sediments remobilization. Seasonal variations were also observed with higher total OM content in SPM and high deoxy $\mathrm{C} 6 / \mathrm{C} 5$ and $\mathrm{C}_{16: 1} / \mathrm{C}_{16: 0}$ ratios during low flow level in summer. These markers traduce the enhancement of autochthonous OM at FRO station during low flow level in summer

These results showed relative similarity of OM composition in SPM through the Moselle catchment with the exception of FLO station. However, we expected more contrasted OM composition because of the heterogeneous land use. The use of other markers such as $\mathrm{Zn}$ isotopic measurements could permit to better separate the different sources of SPM in the 
watershed (SPM from urban, forest or farm areas). In addition, the regime flow sampling in this study was realized during different days and additional sampling during one storm event should be performed in order to better characterize the OM composition variations in relation with regime flow.

\section{Acknowledgments}

This study was performed in the context of the Zone Atelier Moselle (ZAM), which belongs to the French LTER network, and was financially supported by the French CNRS-INEE and Region Lorraine (CPER). The authors thank E. Rotureau and F. Fraysse for their contributions to manuscript reading. In addition, the authors would like to thank SARMCRPG for chemical analyses. The authors also would like to thanks the two anonymous reviewers for their constructive comments.

\section{References}

Bertrand, O., Mansuy-Huault, L., Montargès-Pelletier, E., Faure, P., Losson, B., Argant, J., Ruffaldi, P., Michels, R., 2013. Recent vegetation history from a swampy environment to a pond based on macromolecular organic matter (lignin and fatty acids) and pollen sedimentary records. Organic Geochemistry 64, $47-57$.

Bianchi, T.S., Wysocki, L.A., Stewart, M., Filley, T.R., McKee, B.A., 2007. Temporal variability in terrestrially-derived sources of particulate organic carbon in the lower Mississippi River and its upper tributaries. Geochimica et Cosmochimica Acta 71, 4425 - 4437.

Bibby, R.L., Webster-Brown, J.G., 2006. Trace metal adsorption onto urban stream suspended particulate matter (Auckland region, New Zealand). Applied Geochemistry 21, 1135 - 1151.

Boëchat, I.G., Krüger, A., Chaves, R.C., Graeber, D., Gücker, B., 2014. Land-use impacts on fatty acid profiles of suspended particulate organic matter along a large tropical river. Science of the Total Environment 482, $62-70$.

Budzinski, H., Jones, I., Bellocq, J., Piérard, C., Garrigues, P., 1997. Evaluation of sediment contamination by polycyclic aromatic hydrocarbons in the Gironde estuary. Marine Chemistry 58, 85 -97 .

Challinor, J.M., 1995. Characterization of wood by pyrolysis derivatization-gas chromatography/mass spectrometry. Journal of Analytical and Applied Pyrolysis 35, 93 - 107.

Clifford, D.J., Carson, D.M., McKinney, D.E., Bortiatynski, J.M., Hatcher, P.G., 1995. A new rapid technique for the characterization of lignin in vascular plants: thermochemolysis with tetramethylammonium hydroxide (TMAH). Organic Geochemistry 23, 169 - 175. 
Cole, J.J., Prairie, Y.T., Caraco, N.F., McDowell, W.H., Tranvik, L.J., Striegl, R.G., Duarte, C.M., Kortelaine, P., Downing, J.A., Middelburg, J.J., Melack, J., 2007. Plumbing the global carbon cycle: integrating inland waters into the terrestrial carbon budget. Ecosystems 10, $171-184$.

543 Cole, J., 2013 Freshwater in flux. Nature Geoscience 6, 13 - 14.

544

545

546

547

Countway, R.E., Dickhut, R.M., Canuel, E.A., 2003. Polycyclic aromatic hydrocarbon (PAH) distributions and associations with organic matter in surface waters of the York River, VA Estuary. Organic Geochemistry 34, 209 - 224.

Cowie, G.L., Hedges, J.I., 1984. Carbohydrate sources in a coastal marine-environment. Geochimica et Cosmochimica Acta 48, 2075 - 2087.

Cranwell, P.A., 1974. Monocarboxylic acids in lake sediments: Indicators, derived from terrestrial and aquatic biota, of paleoenvironmental trophic levels. Chemical Geology 14,1-14.

Cranwell, P.A., 1982. Lipids of aquatic sediments and sedimenting particulates. Progress in Lipid Research 21, $271-308$.

Dalzell, B.J., Filley, T.R., Harbor, J.M., 2005. Flood pulse influences on terrestrial organic matter export from an agricultural watershed. Journal of Geophysical Research 110, 1- 14.

Fabbri, D., Chiavari, G., Galletti, G.C., 1996. Characterization of soil humin by pyrolysis (/methylation)-gas chromatography/mass spectrometry: structural relationships with humic acids. Journal of Analytical and Applied Pyrolysis 37, $161-172$.

Fattore, E., Benfenati, E., Marelli, R., Cools, E., Fanelli, R., 1996. Sterols in sediment samples from venice Lagoon, Italy. Chemosphere 33, $2383-2393$.

Filella, M., 2009. Freshwaters: which NOM matters? Environmental Chemical Letter 7, 21 - 35.

Frazier, S.W., Nowack, K.O., Goins, K.M., Cannon, F.S., Kaplan, L.A., Hatcher, P.G., 2003. Characterization of organic matter from natural waters using tetramethylammonium hydroxide thermochemolysis GC-MS. Journal of Analytical and Applied Pyrolysis 70, 99 - 128.

Grasset, L., Rovira, P., Amblès, A., 2009. TMAH-preparative thermochemolysis for the characterization of organic matter in densimetric fractions of a Mediterranean forest soil. Journal of Analytical and Applied Pyrolysis 85, 435 - 441.

Grimalt, J.O., Fernandez, P., Bayona, J.M., Albaiges, J., 1990. Assessment of fecal sterols and ketones as indicators of urban sewage inputs to coastal waters. Environmental Science and Technology 24, 357 -363 .

Hatcher, P.G., McGillivary, P.A., 1979. Sewage contamination in the New York Bight. Coprostanol as an indicator. Environmental Science and Technology 13, 1225 - 1229.

Hatcher, P.G., Clifford, D.J., 1994. Flash pyrolysis and in situ methylation of humic acids from soils. Organic Geochemistry 21, $1081-1092$.

Hedges, J.I., Mann, D.C., 1979. The lignin geochemistry of marine sediments from the southern Washington coast. Geochimica et Cosmochimica Acta 43, 1809 - 1818.

Hedges, J.I., Ertel, J.R., Leopold, E.B., 1982. Lignin geochemistry of a Late Quaternary sediment core from Lake Washington. Geochimica et Cosmochimica Acta 46, 1869 - 1877. 
Hernes, P.J., Spencer, R.G.M., Dyda, R.Y., Pellerin, B.A., Bachand, P.A.M., Bergamaschi, B.A., 2008. The role of hydrologic regimes on dissolved organic carbon composition in an agricultural watershed. Geochimica et Cosmochimica Acta 72, 5266 - 5277.

Hua, X., Dong, D., Liu, L., Gao, M., Liang, D., 2012. Comparison of trace metal adsorption onto different solid materials and their chemical components in a natural aquatic environment. Applied Geochemistry 27, $1005-1012$.

Huang, W.Y., Meinschein, W.G., 1976. Sterols as source indicators of organic materials in sediments. Geochimica et Cosmochimica Acta 40, 323 - 330.

Jardé, E., Gruau, G., Mansuy-Huault, L., 2007. Detection of manure-derived organic compounds in rivers draining agricultural areas of intensive manure spreading. Applied Geochemistry 22, 1814 1824.

Jeanneau, L., Faure, P., Montargès-Pelletier, E., Ramelli, M., 2006. Impact of highly contaminated river on a more important hydrologic system: changes in organic markers. Science of the Total Environment 372, $183-192$.

Jeanneau, L., Faure, P., Montargès-Pelletier, E., 2008 Quantitative multimolecular marker approach to investigate the spatial variability of the transfer of pollution from the Fensch River to the Moselle River (France). Science of the Total Environment 389, $503-513$.

Jeanneau, L., Denis, M., Pierson-Wickkmann, A.C., Gruau, G., Lambert, T., Petitjean, P., 2014. Sources and transfer mechanisms of dissolved organic matter during storm and inter-storm conditions in a lowland headcatchment: constraints from high-frequency molecular data. Biogeosciences Discussions 12, $3349-3379$.

Lartiges, B.S., Deneux-Mustin, S., Villemin, G., Mustin, C., Barrès, O., Chamerois, M., Gerard, B., Babut, M., 2001. Composition, structure and size distribution of suspended particulates from the Rhine River. Water Research 35, $808-816$.

Leeming, R., Ball, A., Ashbolt, N., Nichols, P.D., 1996. Using faecal sterols from humans and animals to distinguish faecal pollution in receiving waters. Water Research 30, $2893-2900$.

Le Meur, M., Montargès-Pelletier, E., Bauer, A., Gley, R., Migot, S., Barres, O., Delus, C., Villiéras, F., 2015. Characterization of suspended particulate matter in the Moselle River (Lorraine, France): evolution along the course of the river and in different hydrologic regimes. Journal of Soil and Sediment 16,1625-1642.

Ludwig, W., Probst, J.L., Kempe, S., 1996. Predicting the oceanic input of organic carbon by continental erosion. Global Biogeochemistry Cycle 10, 23 - 41.

Luo, J., Ma, M., Liu, C., Zha, J., Wang, Z., 2009. Impacts of particulate organic carbon and dissolved organic carbon on removal of polycyclic aromatic hydrocarbons, organochlorine pesticides, and nonyphenols in a wetland. Journal of Soil and Sediment 9, 180-187.

Macdonald, I.A., Bokkenheuser, V.D.,Winter, J., McLernon, A.M., Mosbach, E.H., 1983 Degradation of steroids in the human guts. Journal of Lipid Research 24, $675-700$.

Marin-Spiotta, E., Gruley, K.E., Crawford, J., Atkinson, E.E., Miesel, J.R., Greene, S., CardonaCorrea, C., Spencer, R.G.M., 2014. Paradigm shifts in soil organic matter research affect interpretations of aquatic carbon cycling: transcending disciplinary and ecosystem boundaries. Biogeochemistry 117, $279-297$.

Mason, S.L., Filley, T.R., Abbott, G.D., 2012. A comparative study of the molecular composition of a grassland soil with adjacent unforested and afforested moorland ecosystems. Organic Geochemistry $42,1519-1528$. 
Medeiros, P.M., Simoneit, B.R.T., 2008. Multi-biomarker characterization of sedimentary organic carbon in small rivers draining the Northwestern United States. Organic Geochemistry 39, 52 - 74.

Medeiros, P.M., Sikes, E.L., Thomas, B., Freeman, K.H., 2012. Flow discharge influences on input and transport of particulate and sedimentary organic carbon along a small temperate river. Geochimica et Cosmochimica Acta 77, 317 - 334 .

Meyers, P.A., 2003. Applications of organic geochemistry to paleolimnological reconstructions: a summary of examples from the Laurentian Great Lakes. Organic Geochemistry 34, $261-289$.

Micic, V., Kruge, M.A., Köster, J., Hofmann, T., 2011. Natural, anthropogenic and fossil organic matter in river sediments and suspended particulate matter: a multi-molecular approach. Science of the Total Environment 409, 905 - 919.

Montarges-Pelletier, E., Jeanneau, L., Faure, P., Bihannic, I., Barres, O., Lartiges, B., 2007. The junction of Fensch and Moselle rivers, France; mineralogy and composition of river materials. Environmental Geology 53, $85-102$.

Montarges-Pelletier, E., Duriez, C., Ghanbaja, J., Jeanneau, L., Falkenberg, G., Michot, L.J., 2014. Microscale investigations of the fate of heavy metals associated to iron-bearing particles in a highly polluted stream. Environmental Science Pollution Research 21, 2744 - 2760.

Ni, H.G., Lu, F.H., Luo, X.L., Tian, H.Y., Zeng, E.Y., 2008. Riverine inputs of total organic carbon and suspended particulate matter from the Pearl River Delta to the coastal ocean off South China. Marine Pollution Bulletin 56, 1150 - 1157.

Nishimura, M., Koyama, T., 1977. The occurrence of stanols in various living organisms and the behavior of sterols in contemporary sediments. Geochimica et Cosmochimica Acta 41, 379-385.

Punning J.M., Terasmaa J., Vaasma T., Kapanen G., 2008. Historical changes in the concentrations of polycyclic aromatic hydrocarbons (PAHs) in lake Peipsi sediments. Environmental Monitoring and Assessment 144, $131-141$.

Qiao, M., Qi, W., Liu, H., Qu, J., 2014. Oxygenated, nitrated, methyl and parent polycyclic aromatic hydrocarbons in rivers of Haihe River system, China: occurrence, possible formation, and source and fate in a water-shortage area. Science of the Total Environment 481, $178-185$.

Quéméneur, M., Marty, Y., 1994. Fatty acids and sterols in domestic wastewaters. Water Research 28, $1217-1226$.

Reeves, A.D., Patton, D., 2005. Faecal sterols as indicators of sewage contamination in estuarine sediments to the Tay Estuary, Scotland: an extended baseline survey. Hydrology and earth System Science $9,81-94$.

Réveillé, V., Mansuy, L., jardé, E., Garnier-Silam, E., 2003. Characterization of sewage sludgederived organic matter: lipids and humic acids. Organic Geochemistry 34, $615-627$.

Rieley, G., Collier, R.J., Jones, D.M., Eglinton, G., 1991. The biogeochemistry of Ellesmere Lake, UK - I: source correlation of leaf wax inputs to the sedimentary lipid record. Organic Geochemistry 17, $901-912$.

Rumpel, C., Dignac, M.-F, 2006. Gas chromatographic analysis of monosaccharides in a forest soil profile: Analysis by gas chromatography after trifluoroacetic acid hydrolysis and reductionacetylation. Soil Biology and Biochemistry 38, $1478-1481$. 
Shi, Z., Tao, S., Pan, B., Fan, W., He, X.C., Zuo, Q., Wu, S.P., Li, B.G., Cao, J., Liu, W.X., Xu, F.L., Wang, X.J., Shen, W.R., Wong, P.K., 2005. Contamination of rivers in Tianjin, China by polycyclic aromatic hydrocarbons. Environmental Pollution 134, 97 - 111.

Union europeenne - Soes, Corine Land Cover (2006)

Volkman, J.K., Eglinton, G., Corner, E.D.S., Sargent, J.R., 1980. Novel unsaturated straight-chain C37-C39 methyl and ethyl ketones in marine sediments and a coccolithophore Emiliana Huxleyi. Physics and Chemistry of the Earth 12, $219-227$.

Volkman, J.K., 1986. A review of sterol markers for marine and terrigenous organic matter. Organic Geochemistry 9, 83-99.

Volkman, J.K., 2003. Sterols in microorganisms. Applied Microbiology and Biotechnology 60, 495 506.

Ward, N.D., Krusche, A.V., Sawakuchi, H.O., Brito, D.C., Cunha, A.C., Sousa Moura, J.M., da Silva Yager, P.L., Keil, R.G., Richey, J.E., 2015. The compositional evolution of dissolved and particulate organic matter along the lower Amazon River - Obidos to the ocean. Marine Chemistry 177, 244 256.

Wetzel, R.G., 2001. Limnology: Lake and river ecosystems, $3^{\text {rd }}$ ed., Academic Press

Wicks, R.J., Moran, M.A., Pittman, L.J., Hodson, R.E., 1991. Carbohydrates signatures of aquatic macrophytes and their dissolved degradation products as determined by a sensitive high-performance ion chromatography method. Applied Environmental Microbiology 57, 3135 - 3143.

Yunker, M.B., Macdonald, R.W., Vingarzan, R., Reginald, H.M., Goyette, D., Sylvestre, S., 2002. PAHs in the Fraser River basin: a critical appraisal of PAH ratios as indicators of PAH source and composition. Organic Geochemistry 33, 489-515. 
Table 1

A. Background data for the different stations (Corine Land Cover, 2006)

\begin{tabular}{|c|c|c|c|c|c|c|c|}
\hline Code & Town & Sample site & $\begin{array}{l}\text { Watershed } \\
\text { surface } \\
\text { area }\left(\mathrm{km}^{2}\right)\end{array}$ & $\begin{array}{c}\text { GPS } \\
\text { coordinates }\end{array}$ & $\begin{array}{l}\text { Urbanized } \\
\text { area }(\%)^{\mathrm{a}}\end{array}$ & $\begin{array}{l}\text { Cultivated } \\
\text { area }(\%)\end{array}$ & $\begin{array}{l}\text { Forest } \\
(\%)\end{array}$ \\
\hline FLA & Flavigny & Residential area & 2013 & $\begin{array}{l}6^{\circ} 11^{\prime} 19.5^{\prime \prime} \mathrm{E} \\
48^{\circ} 34^{\prime} 11.7^{\prime \prime} \mathrm{N}\end{array}$ & 6.0 & 38.3 & 55.3 \\
\hline $\mathrm{PSV}^{\mathrm{b}}$ & $\begin{array}{l}\text { Pont Saint } \\
\text { Vincent }\end{array}$ & $\begin{array}{l}\text { Agricultural } \\
\text { catchment }\end{array}$ & 1036 & $\begin{array}{c}6^{\circ} 06^{\prime} 21.6^{\prime \prime} \mathrm{E} \\
48^{\circ} 36^{\prime} 02.1^{\prime \prime} \mathrm{N}\end{array}$ & 3.0 & 77.2 & 19.8 \\
\hline FRO & Frouard & $\begin{array}{c}\text { Upstream of junction } \\
\text { with Moselle }\end{array}$ & 3768 & $\begin{array}{c}6^{\circ} 08^{\prime} 11.8^{\prime \prime} \mathrm{E} \\
48^{\circ} 46^{\prime} 30.4{ }^{\prime \prime} \mathrm{N}\end{array}$ & 6.1 & 49.1 & 43.6 \\
\hline $\mathrm{BOU}^{\mathrm{b}}$ & $\begin{array}{l}\text { Bouxières } \\
\text { aux dames }\end{array}$ & $\begin{array}{c}\text { Downstream of } \\
\text { Nancy city }\end{array}$ & 3055 & $\begin{array}{c}6^{\circ} 08^{\prime} 58.5^{\prime \prime} \mathrm{E} \\
48^{\circ} 45^{\prime} 22.7^{\prime \prime} \mathrm{N}\end{array}$ & 6.7 & 43.7 & 49.3 \\
\hline MIL & Millery & Residential area & 6830 & $\begin{array}{l}6^{\circ} 07^{\prime} 37.0^{\prime \prime} \mathrm{E} \\
48^{\circ} 48^{\prime} 53.1^{\prime \prime} \mathrm{N}\end{array}$ & 6.2 & 47.1 & 46.5 \\
\hline PAM & $\begin{array}{l}\text { Pont à } \\
\text { Mousson }\end{array}$ & $\begin{array}{l}\text { Downstream the city } \\
\text { limits }\end{array}$ & 7209 & $\begin{array}{l}6^{\circ} 02^{\prime} 39.0^{\prime \prime} \mathrm{E} \\
48^{\circ} 56^{\prime} 06.11^{\prime \prime} \mathrm{N}\end{array}$ & 6.1 & 47.6 & 45.9 \\
\hline ARG & Argancy & $\begin{array}{c}\text { Downstream of Metz } \\
\text { city }\end{array}$ & 9213 & $\begin{array}{l}6^{\circ} 11^{\prime} 59.9^{\prime \prime} \mathrm{E} \\
49^{\circ} 08^{\prime} 38.66^{\prime} \mathrm{N}\end{array}$ & 6.0 & 52.5 & 40.9 \\
\hline $\mathrm{RIC}^{\mathrm{b}}$ & Richemont & $\begin{array}{c}\text { Downstream of city } \\
\text { limit }\end{array}$ & 1276 & $\begin{array}{l}6^{\circ} 10^{\prime} 23.5^{\prime \prime} \mathrm{E} \\
49^{\circ} 16^{\prime} 48.66^{\prime \prime} \mathrm{N}\end{array}$ & 6.0 & 67.0 & 26.5 \\
\hline $\mathrm{FLO}^{\mathrm{b}}$ & Florange & Industrial catchment & 59 & $\begin{array}{c}6^{\circ} 08^{\prime} 05.4^{\prime \prime} \mathrm{E} \\
49^{\circ} 19^{\prime} 55.2^{\prime \prime} \mathrm{N}\end{array}$ & 33.0 & 22.2 & 44.9 \\
\hline THI & Thionville & In Thionville city & 10882 & $\begin{array}{l}6^{\circ} 10^{\prime} 26.4^{\prime \prime} \mathrm{E} \\
49^{\circ} 21^{\prime} 30.66^{\prime} \mathrm{N}\end{array}$ & 6.7 & 53.9 & 38.7 \\
\hline
\end{tabular}

a Urbanized surface (\%)

${ }^{\mathrm{b}}$ Station on a Moselle tributary: PSV, Madon: BOU, Meurthe; RIC, Orne; FLO, Fensch. 
.Table 2 Water data for Moselle catchment (Hydro Eau France, 2015).

\begin{tabular}{|c|c|c|c|c|c|c|}
\hline Station & Date & \multicolumn{2}{|c|}{ Water discharge $\left(\mathrm{m}^{3} / \mathrm{s}\right)$} & $\begin{array}{c}\text { Water } \\
\text { temperature }\end{array}$ & Turb. (NTU) & $\mathrm{SPM}(\mathrm{mg} / \mathrm{l})$ \\
\hline FLA & $16 / 10 / 2012$ & \multicolumn{2}{|c|}{71} & 6.6 & 3.5 & $2.9 *$ \\
\hline PSV (Ma) & $29 / 11 / 2012$ & \multicolumn{2}{|r|}{7} & 6.8 & $7.7 \pm 0.2$ & $8.8 \pm 1.7$ \\
\hline PSV (Ma) & $20 / 12 / 2012$ & \multicolumn{2}{|c|}{28} & 5.4 & $43.5 \pm 1.0$ & $46.4 \pm 5.0$ \\
\hline FRO & $27 / 11 / 2012$ & \multicolumn{2}{|c|}{82} & 7.8 & $2.8 \pm 0.2$ & $2.1^{*}$ \\
\hline FRO & $17 / 12 / 2012$ & 397 & (storm) & 6.6 & $85.0 \pm 3.6$ & $90.2 \pm 6.4$ \\
\hline FRO & $19 / 06 / 2013$ & 35 & (low water) & 25.4 & $5.2 \pm 0.8$ & $6.2 \pm 0.3$ \\
\hline FRO & $17 / 07 / 2013$ & 15 & (low water) & 23.5 & $3.7 \pm 0.6$ & $3.1 \pm 0.7$ \\
\hline FRO & $16 / 10 / 2013$ & 394 & (storm) & 11 & $27.5 \pm 3$ & $29.6^{*}$ \\
\hline FRO & $8 / 11 / 2013$ & \multicolumn{2}{|c|}{198} & - & $20.9 \pm 0.2$ & $22.3 *$ \\
\hline FRO & $18 / 12 / 2013$ & 36 & (low water) & 4.8 & $3 \pm 0.3$ & $5.6 \pm 1.7$ \\
\hline FRO & $15 / 01 / 2014$ & \multicolumn{2}{|c|}{104} & 6 & $6.17 \pm 0.05$ & $3.65 \pm 0.82$ \\
\hline FRO & $19 / 02 / 2014$ & \multicolumn{2}{|c|}{124} & 6 & $32.9 \pm 1.8$ & $16 \pm 3.9$ \\
\hline FRO & $16 / 10 / 2014$ & 44 & (low water) & - & - & - \\
\hline $\begin{array}{l}\mathrm{BOU} \\
(\mathrm{Me})\end{array}$ & $15 / 05 / 2015$ & \multicolumn{2}{|c|}{35} & 11.4 & 6 & $5.9 \pm 1.7$ \\
\hline MIL & $16 / 10 / 2012$ & \multicolumn{2}{|c|}{136} & 9.9 & 4.6 & $4.1^{\mathrm{b}}$ \\
\hline PAM & $20 / 11 / 2012$ & & 7.7 & 3.8 & $3.2^{\mathrm{b}}$ \\
\hline PAM & $6 / 2 / 2013$ & \multicolumn{2}{|c|}{475} & 4.8 & $37.2 \pm 1.2$ & $36.2 \pm 6.0$ \\
\hline $\mathrm{ARG}$ & $13 / 11 / 2012$ & \multicolumn{2}{|c|}{171} & 8.9 & 19.2 & $20.4^{\mathrm{b}}$ \\
\hline RIC (O) & $30 / 04 / 2013$ & \multicolumn{2}{|r|}{8} & 9.6 & 1.4 & $3.0 \pm 0.7$ \\
\hline FLO (F) & $9 / 10 / 2012$ & \multicolumn{2}{|r|}{1} & 14.9 & 4.7 & $4.2^{\mathrm{b}}$ \\
\hline THI & $6 / 12 / 2012$ & \multicolumn{2}{|c|}{200} & 5.5 & $7.1 \pm 0.6$ & $7.5 \pm 0.1$ \\
\hline
\end{tabular}

${ }^{a}$ River water discharge data taken from the hydrometric station in Toul for FLA and FRO, in Pulligny for PSV, in Custine for MIL, PAM and ARG, in Rosselange for RIC, in Knutange for FLO, and in Hagondange for THI; Ma refers to Madon River, Me to Meurthe River, O to Orne River, and F to Fensch River. ${ }^{b}$ SPM concentration extrapolated from turbidity values 
Table 3 Data for the different samples from Moselle River watershed: regime flow $\left(\mathrm{Q}, \mathrm{m}^{3} \cdot \mathrm{s}^{-1}\right)$; $\mathrm{C}_{16: 1} / \mathrm{C}_{16 / 0}$ ) ratio; Deoxy $\mathrm{C6} / \mathrm{C} 5$ ratio, $\mathrm{C} / \mathrm{V}$ ratio; $\mathrm{Ad} / \mathrm{Al}_{(\mathrm{v})}$ ratio

\begin{tabular}{cccccc}
\hline Station & $\mathrm{Q}\left(\mathrm{m}^{3} / \mathrm{s}\right)$ & $\mathrm{C}_{16: 1} / \mathrm{C}_{16: 0}$ & $\begin{array}{c}\text { Deoxy } \\
\mathrm{C} 6 / \mathrm{C} 5\end{array}$ & $\mathrm{C} / \mathrm{V}$ & $\mathrm{Ad} / \mathrm{Al}(\mathrm{v})$ \\
\hline FLA & 71 & 0.22 & 0.52 & 0.58 & 2.12 \\
PSV $^{*}$ nov12 & 7 & 0.15 & 0.46 & 0.49 & 1.45 \\
PSV $^{*}$ dec12 & 28 & 0.10 & 0.42 & 0.33 & 1.59 \\
FRO jul13 & 15 & 0.36 & 0.57 & 0.50 & 1.38 \\
FRO jun13 & 35 & 0.17 & 0.48 & 0.65 & 1.77 \\
FRO dec13 & 36 & 0.24 & - & 0.42 & 1.44 \\
FRO oct14 & 44 & 0.46 & - & 0.51 & 1.87 \\
FRO nov12 & 82 & 0.16 & 0.55 & 0.44 & 1.86 \\
FRO feb14 & 124 & 0.14 & 0.55 & 0.40 & 1.86 \\
FRO nov13 & 198 & 0.61 & - & 0.68 & 2.96 \\
FRO dec12 & 397 & 0.06 & 0.54 & 0.36 & 2.04 \\
BOU & 35 & 0.60 & 0.65 & 0.47 & 1.72 \\
MIL & 136 & 0.44 & 0.65 & 0.52 & 1.77 \\
PAM nov12 & 81 & 0.10 & 0.55 & 0.49 & 2.24 \\
PAM fev13 & 475 & 0.08 & 0.45 & 0.92 & 2.7 \\
ARG & 171 & 0.25 & 0.54 & 0.42 & 1.36 \\
FLO & 1 & 0.36 & 0.56 & 0.38 & 1.87 \\
RIC & 8 & 0.63 & 0.77 & 1.12 & 2.5 \\
THI & 200 & 0.34 & 0.54 & 0.34 & 1.76 \\
\hline
\end{tabular}




\section{Table 4}

Coprostanol/Cholesterol, C29/C27 $7_{(\mathrm{ST})}$ and $\mathrm{C}_{16: 1} / \mathrm{C}_{16: 0}$ from peak area of each product for the different Moselle catchment SPM samples in the lipidic fraction

\begin{tabular}{ccccc}
\hline Station date & Coprostanol/Cholesterol & $\mathrm{C}_{29} / \mathrm{C}_{27(\mathrm{ST})}$ & $\mathrm{C}_{16: 1} / \mathrm{C}_{16: 0}$ & Flow regime $\mathrm{m}^{3} / \mathrm{s}$ \\
\hline FLA nov12 & 2.05 & 1.29 & 0.18 & 71 \\
PSV nov 12 & 1.47 & 1.22 & 0.13 & 7 \\
FRO nov 12 & 0.79 & 0.01 & 82 \\
FRO jun13 & 2.58 & 0.28 & 0.43 & 35 \\
FRO jul13 & 0.21 & 0.69 & 0.52 & 15 \\
FRO oct 13 & 0.24 & 1.39 & 0.07 & 394 \\
FRO feb14 & 0.92 & 1.49 & 0.32 & 124 \\
MIL oct12 & 1.14 & 0.91 & 0.18 & 136 \\
BOU mar15 & 1.97 & 0.99 & 0.19 & 35 \\
PAM nov12 & 2.41 & 0.72 & 0.06 & 81 \\
PAM fev 13 & 1.26 & 1.12 & 0 & 475 \\
ARG nov12 & 2.90 & 1.22 & 0.13 & 171 \\
FLO oct12 & 1.03 & 0.46 & 0.04 & 1 \\
THI dec12 & 2.90 & 1.02 & 0.05 & 200
\end{tabular}


Table 5 PAHs in the Moselle SPM $\left(\mu \mathrm{g} . \mathrm{g}^{-1}\right)$

\begin{tabular}{|c|c|c|c|c|c|c|c|}
\hline Station & ¿16PAHs & ¿8PAHs & An/178 & $\mathrm{BaA} / 228$ & $\mathrm{Fl} / 202$ & $\begin{array}{l}\text { \% of } \\
\text { LMW }\end{array}$ & $\%$ of $\mathrm{HMW}$ \\
\hline FLA & 4.69 & 2.8 & 0 & 0.54 & 0.54 & 9.11 & 90.89 \\
\hline PSV nov 12 & 5.33 & 3.3 & 0.42 & 0.54 & 0.56 & 12.04 & 87.96 \\
\hline PSV dec12 & 4.95 & 3.07 & 0.37 & 0.55 & 0.58 & 10.91 & 89.09 \\
\hline FRO juil13 & 3.67 & 2.28 & 0.36 & 0.53 & 0.54 & 11.33 & 88.67 \\
\hline FRO jun13 & 4.71 & 2.98 & 0.36 & 0.53 & 0.56 & 10.43 & 89.57 \\
\hline FRO dec13 & 3.33 & 1.73 & 0.36 & 0.58 & 0.59 & 28.67 & 71.33 \\
\hline FRO jan14 & 5.12 & 2.59 & 0.39 & 0.57 & 0.59 & 30.26 & 69.74 \\
\hline FRO oct14 & 4.98 & 3.08 & 0.48 & 0.55 & 0.55 & 12.11 & 87.89 \\
\hline FRO feb14 & 2.96 & 1.87 & 0.39 & 0.54 & 0.54 & 8.52 & 91.48 \\
\hline FRO nov13 & 4.88 & 2.78 & 0.5 & 0.56 & 0.54 & 28.2 & 71.8 \\
\hline FRO oct 13 & 3.95 & 2.21 & 0 & 1 & 0.43 & 22.88 & 77.12 \\
\hline BOU & 5.79 & 3.96 & 0.41 & 0.55 & 0.56 & 27.94 & 72.06 \\
\hline MIL & 7.66 & 4.74 & 0.55 & 0.4 & 0.75 & 17.64 & 82.36 \\
\hline PAM nov 12 & 4.47 & 2.78 & 0.3 & 0.55 & 0.55 & 12.01 & 87.99 \\
\hline PAM fev13 & 4.66 & 2.94 & 0.29 & 0.51 & 0.59 & 10.22 & 89.78 \\
\hline ARG & 3.61 & 2.17 & 0.3 & 0.57 & 0.58 & 12.19 & 87.81 \\
\hline RIC & 3.97 & 2.48 & 0.46 & 0.53 & 0.55 & 21.42 & 78.58 \\
\hline FLO & 4.36 & 2.59 & 0.31 & 0.54 & 0.56 & 11.95 & 88.05 \\
\hline $\mathrm{THI}$ & 2.29 & 1.35 & 0 & 0.53 & 0.59 & 11.99 & 88.01 \\
\hline
\end{tabular}

${ }^{a}$ The European Union guideline for the evaluation of contamination in sediments (Directive No. 2000/60/CE - circular DCE 2005/12) takes into account the sum of 8 PAHs for which the regulatory content values are (in $\mu \mathrm{g} / \mathrm{g})$ : naphthalene $(\mathrm{Na}, 0.048)$, anthracene (A, 0.034), fluoranthene (Fl, 0.083), indeno(1.2.3cd)perylene (IP, 0.560), benzo(b)fluoranthene (BbF, 0.170), benzo(k)fluoranthene (BkF, 0.140), benzo(a)pyrene (BaP, 7.600$)$ and benzo(g,h,i)perylene (Bghi, 0.140); An/178: anthracene/(anthracene+phenanthrene); BaA/228, benzo(a)anthracene/(benzo(a)anthracene+chrysene);

Fl/202,fluoranthene/fluoranthene+pyrene; HMW: 4 to 6 rings; LMW: 2-3 rings; 


\section{Figure captions}

Fig. 1. Moselle River catchment showing the main rivers (blue); urbanized areas (grey), cultivated areas (yellow), and forest (green) (Corine Land Cover, 2006). This figure also shows sampling stations (red points). On Moselle River, from upstream to downstream: Flavigny (FLA), Frouard (FRO), Millery (MIL), Pont à Mousson (PAM), Argancy (ARG), Thionville (THI), on Madon River, Pont-Saint-Vincent (PSV), on Meurthe River, Bouxières aux dames (BOU), on Orne River, Richemont (RIC), and on Fensch River, Florange (FLO).

Fig. 2. Evolution of OM content of Moselle SPM (estimated from DSC and TG curves (see Supplementary material A2); black squares: all SPM samples; grey diamonds: SPM samples from Frouard station.

Fig. 3. Composition of Ref-FAs in Moselle SPM for samples collected in November 2012 from four different stations; Flavigny (FLA), Frouard (FRO), Pont-a-Mousson (PAM) and for Florange sample (FLO).

Fig. 4. Composition of Lip-FAs in Moselle SPM for samples collected in November 2012 from four stations: Flavigny (FLA), Pont-a-Mousson (PAM) Frouard (FRO) and Florange sample (FLO).

Fig. 5. Composition of sterols in Moselle SPM for samples collected from four stations: Flavigny (FLA), Pont-àMousson (PAM), Frouard (FRO) and for Florange (FLO).

Fig. 6. SPM weight loss $(\%), \mathrm{C} / \mathrm{V}$ and $\mathrm{Ad} / \mathrm{Al}_{(\mathrm{v})}$ ratios vs. water discharge $\left(\mathrm{m}^{3} / \mathrm{s}\right)$. 

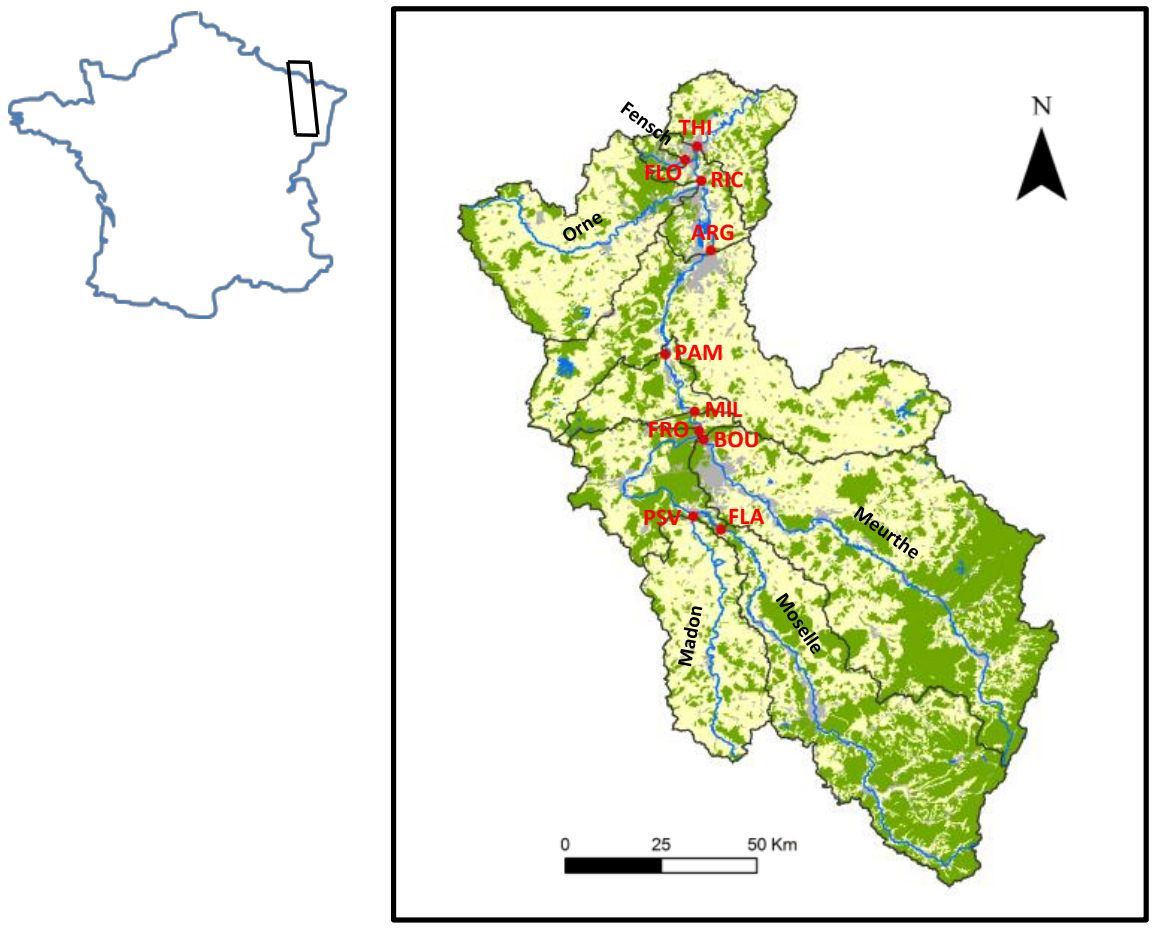


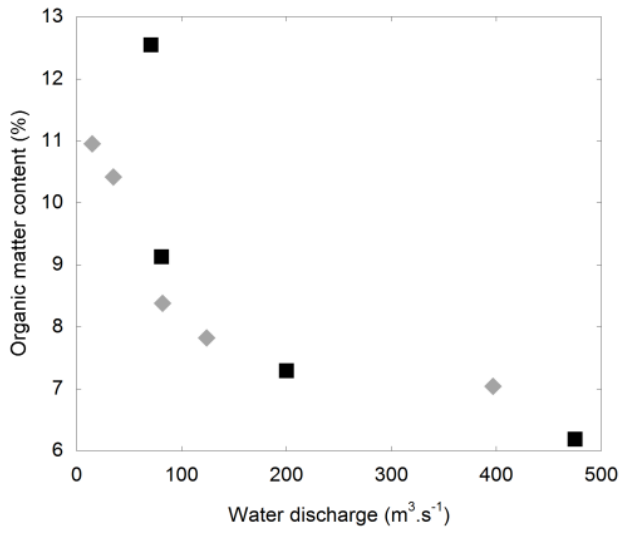




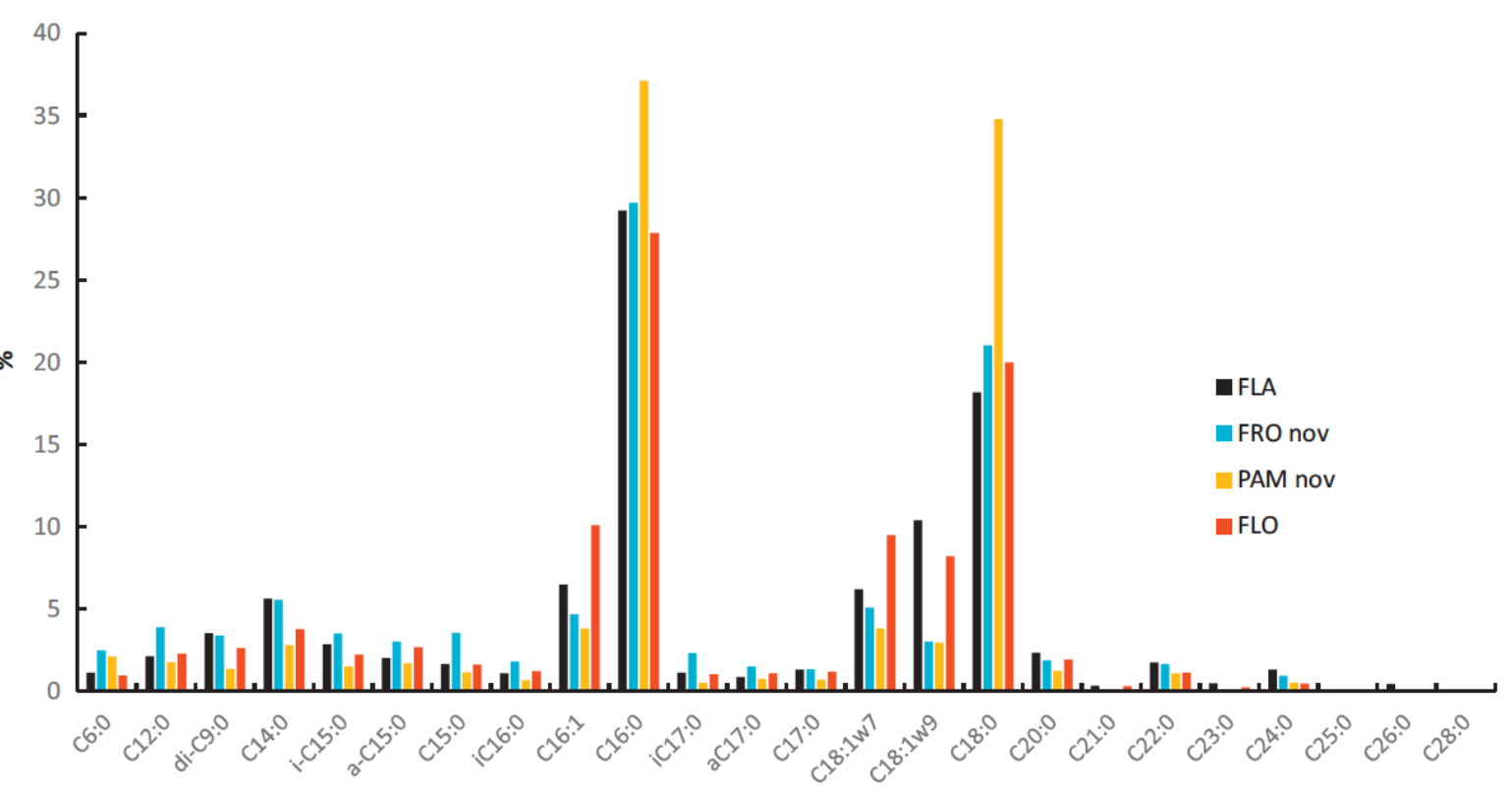




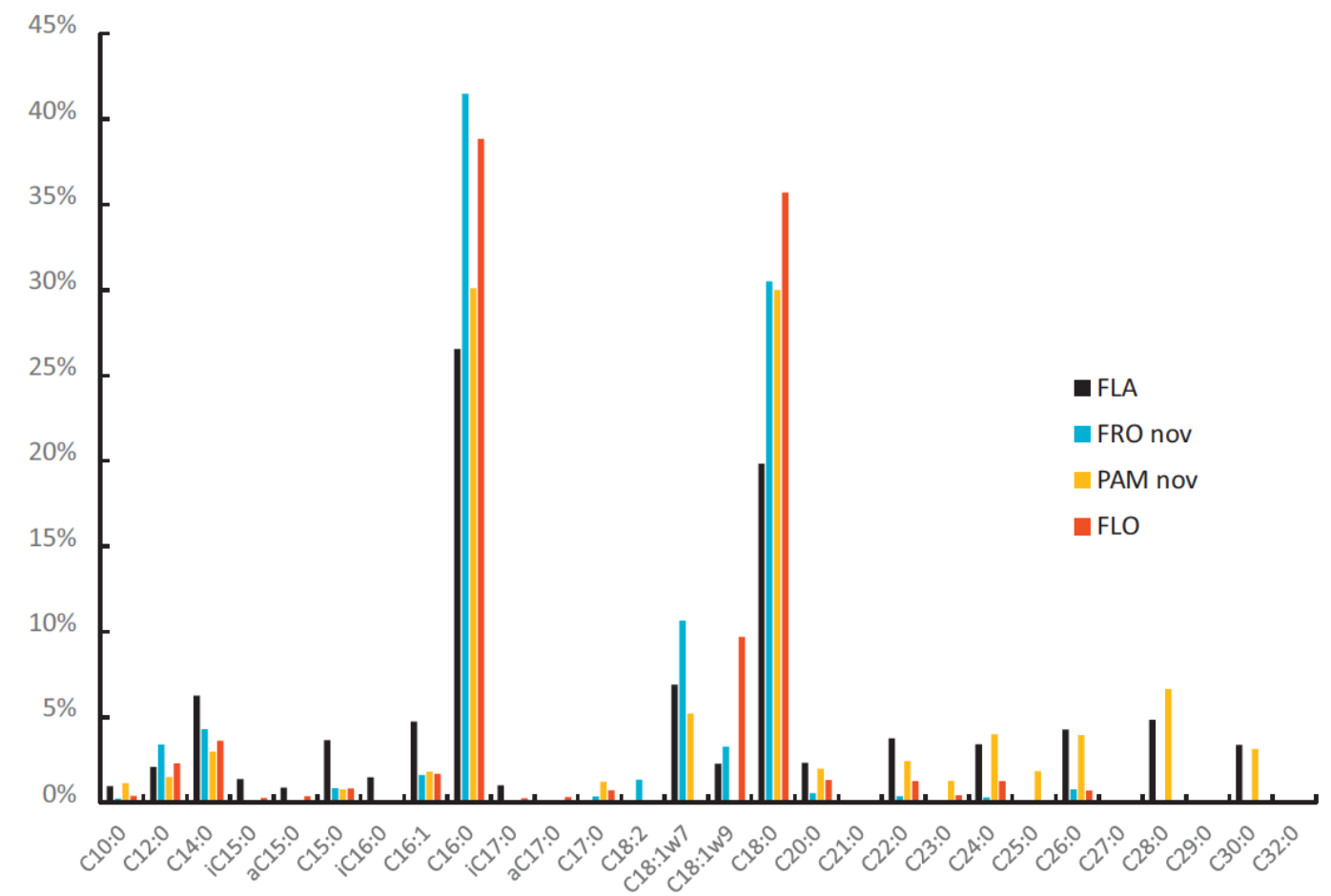




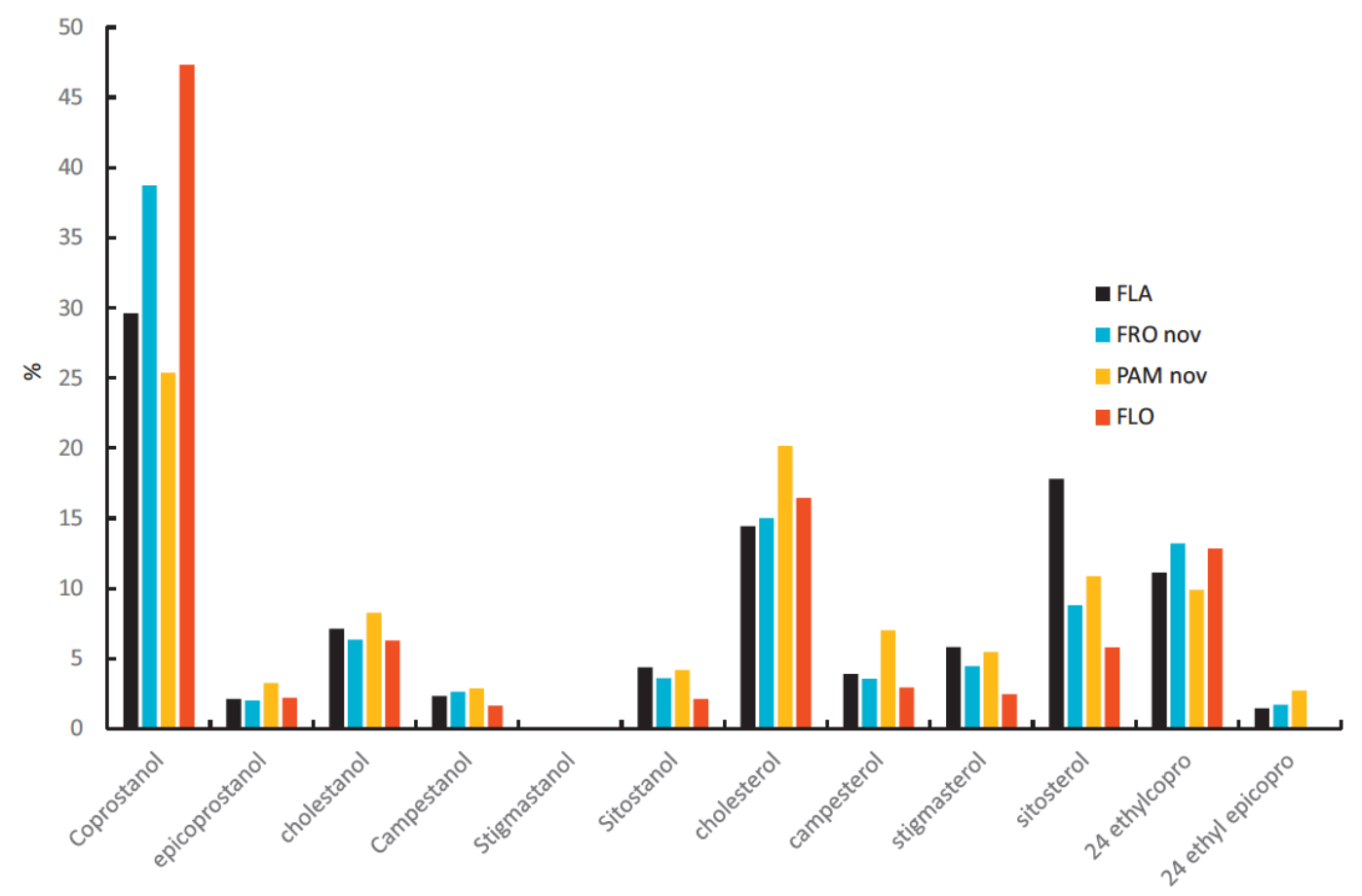




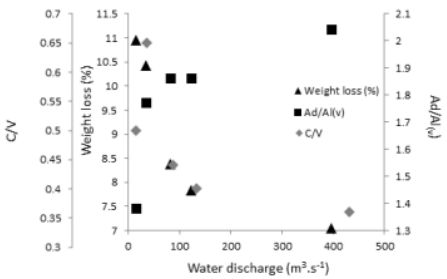


Highlights

SPM was collected along the Moselle River and for different regime flow and seasons.

SPM organic markers from the lipidic and the refractory fractions were characterized.

Fensch River showed higher microbial contribution, highlighting urbanized areas.

The Regime flow engendered OM content decrease and more degraded OM.

Seasonal variations were recorded with high autochthonous contribution during summer. 